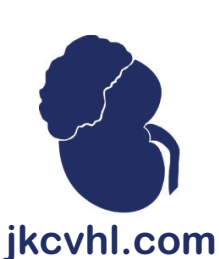

REVIEW ARTICLE

\title{
Management of Renal Cell Carcinoma-Current Practice in Sub-Saharan Africa
}

\author{
Ayun Cassell ${ }^{1}$, Mohamed Jalloh ${ }^{1}$, Bashir Yunusa ${ }^{2}$, Medina Ndoye ${ }^{1}$, Mouhamadou M. Mbodji ${ }^{1}$, \\ Abdourahmane Diallo ${ }^{1}$, Saint Charles Kouka ${ }^{3}$, Issa Labou ${ }^{1}$, Lamine Niang ${ }^{1}$, Serigne M. Gueye ${ }^{1}$
}

${ }^{1}$ Department of Urology and Andrology, Hopital General de Grand Yoff, Dakar, Senegal; ${ }^{2}$ Department of Surgery, Liberia College of Physicians and Surgeons, Monrovia, Liberia; ${ }^{3}$ UFR Sante, Universite de Thies, Thies, Senegal

\begin{abstract}
There is a global variation in the incidence of renal masses with the developed nations having a greater incidence. About $80-90 \%$ of renal malignancies are renal cell carcinomas (RCC) which account for $2-4 \%$ of all cancers. In Africa and the Middle East, the age-standardized incidence for RCC is 1.8-4.8/100,000 for males and 1.2-2.2/100,000 for females. The management of renal cell cancer is challenging. A multidisciplinary approach is effective for diagnosis, staging, and treatment. Guidelines recommend active surveillance, thermal ablation, partial nephrectomy, radical nephrectomy, cytoreductive nephrectomy and immunotherapy as various modalities for various stages of RCC. However, open radical nephrectomy is most widely adopted as an option for treatment at various stages of the disease in sub-Saharan Africa due to its cost-effectiveness, applicability at various stages, and the reduced cost of follow-up. Nevertheless, most patients in the region present with the disease in the advanced stage and despite surgery the prognosis is poor.
\end{abstract}

Keywords: immuotherapy; management; radical nephrectomy; renal cell carcinoma; sub-saharan africa

Received: August 27, 2019; Accepted after revision: November 1, 2019; Published: December 2, 2019.

Author for correspondence: Ayun Cassell, Department of Urology and Andrology, Hopital General de Grand Yoff, Dakar, Senegal, Tel: 221770135805. Email: ayuncasselliii@gmail.com

How to cite: Cassell A et al. Management of Renal Cell Carcinoma_Current Practice in Sub-Saharan Africa. J Kidney Cancer VHL 2019;6(2): 1-9.

Doi: http://dx.doi.org/10.15586/jkcvhl.2019.122

Copyright: Cassell A et al.

License: This open access article is licensed under Creative Commons Attribution 4.0 International (CC BY 4.0). http://creativecommons.org/ licenses/by/4.0

\section{Introduction}

There is a global variation in the incidence of renal masses with the developed nations having a greater incidence (1). GLOBOCAN has estimated that approximately 300,000 men and women were diagnosed with renal cancer globally and nearly 150,000 renal cancer-related deaths occurred in 2012 (2). In 2018, the global incidence was 403,262 with 175,098 deaths reported by GLOBOCAN (3). About $80-90 \%$ of renal malignancies are renal cell carcinomas (RCCs) which account for $2-4 \%$ of all cancers (4). In Africa and the Middle East, the age-standardized incidence for RCC is $1.8-4.8 / 100,000$ for males and 1.2-2.2/100,000 for females (2). A review by Atanda and Haruna in 2017 estimated the incidence of RCC in Nigeria as approximately $0.3 / 100,000$ of the population (5). 
The morbidity and mortality of renal malignancy have reduced or remained steady in developed nations, but this finding cannot be postulated for the disease in sub-Saharan nations. Major risk factors and etiologies identified include smoking, hypertension, obesity, and familial RCC syndrome (1). However, moderate alcohol intake and consumption of fruits and vegetables have proven to have a protective action $(6,7)$.

The management of renal cell cancer is challenging. A multidisciplinary approach is effective for the diagnosis, staging, and treatment. Available guidelines from the American Urological Association (1), European Association of Urology (8), and Canadian Urological Association (9) show a consensus on partial nephrectomy, radical nephrectomy, anti-angiogenic/immunotherapy, and cytoreductive therapy as treatment options for RCC based on the staging. In 2015, Zekri and colleagues published a guideline for clear cell renal carcinoma for Middle East Countries and Africa emphasizing on a multidisciplinary board for renal malignancy due to the complexity of treatment options (4).

Whether the recommendations set by these guideline have been fully adopted into clinical practice in the sub-Saharan region remains unknown. It is relevant that a consensus on the management of renal masses is reached in a regional context that is clinically applicable. We therefore present findings from the Western sub-Saharan nations on the management of RCC to stimulate a development of a regional consensus.

\section{Methodology}

A thorough search of the available literature was conducted by reviewing publications from 1996 to 2019 using the search engines PubMed, Google Scholar, African Journal Online, and Cochrane Library. The search terms used included "Management of Renal Masses" appended with the following indices: Guidelines, Africa, Sub-Saharan Africa, Senegal, Liberia, Ghana, Nigeria, Burkina, Mali, Togo, Ivory Coast, Kenya, Uganda. There were a total of 209 study results and only 30 studies were included in the review. These included clinical guidelines, systemic reviews and meta-analysis, randomized trials, prospective and retrospective studies. The review considered papers dealing with adult renal tumors only. All pediatric renal lesions were excluded.

Eleven published papers from the sub-Saharan region were included for cross-tabulation of data. Both the abstracts and full texts were reviewed for demographics, age, gender, duration of symptoms, clinical presentation, risk factors, associated complication, diagnostic imaging modalities, tumor consistency, tumor size, clinical staging, histological type, treatment option, rate of recurrence, and outcome. The results of the literature search are reflected in Tables 1-4. A quantitative analysis of the data retrieved is represented in the main text of the results using pool analysis of age, gender, duration of symptoms, and clinical presentation. The risk factors, complications, diagnostic modalities, and outcomes were analyzed qualitatively as depicted in the following section.

\section{Results from the Retrieved Literature}

There were 11 published papers from the sub-Saharan region (10-20) including Senegal, Togo, Nigeria, and Benin which discussed the management of renal tumors. A total

Table 1: Demographics, age distribution, and duration of symptoms in patients with renal cell carcinoma

\begin{tabular}{|c|c|c|c|c|c|c|c|}
\hline \multirow{2}{*}{ Study } & \multirow{2}{*}{$\begin{array}{l}\text { Number of } \\
\text { patients }\end{array}$} & \multicolumn{2}{|c|}{ Gender distribution } & \multicolumn{2}{|c|}{ Age distribution in years } & \multicolumn{2}{|c|}{$\begin{array}{c}\text { Duration of } \\
\text { symptoms in months }\end{array}$} \\
\hline & & Male (\%) & Female (\%) & Mean age & Age range & Mean & Range \\
\hline Tengue et al. (Togo) (10) & 32 & 46.9 & 53.1 & $48.1 \pm 10.8$ & $31-75$ & $8.6+7.8$ & $1-48$ \\
\hline Fall et al. (Senegal) (11) & 74 & 48.7 & 51.3 & 49 & $18-72$ & 10 & $1-96$ \\
\hline Gueye et al. (Senegal) (12) & 42 & & & 51 & $18-83$ & 14 & \\
\hline Ahmed et al. (Nigeria) (13) & 61 & 37.4 & 62.6 & 44 & $15-70$ & 12 & $1-192$ \\
\hline Tijani et al. (Nigeria) (14) & 64 & 37.5 & 62.5 & 41.8 & $20-75$ & & \\
\hline Mbaeri et al. (Nigeria) (15) & 19 & 26.3 & 73.4 & $52.6+15.8$ & $22-75$ & & \\
\hline Avakoudjo et al. (Benin) (16) & 46 & 60.9 & 39.1 & 54 & $19-83$ & & \\
\hline Coulibaly et al. (Burkina Faso) (17) & 24 & 41.7 & 58.3 & $48.2 \pm 8.02$ & $17-82$ & & \\
\hline Muhammed et al. (Nigeria) (18) & 51 & 33.3 & 66.7 & 43.1 & & & \\
\hline Badmus et al. (Nigeria) (19) & 18 & 61.6 & 38.4 & 47.5 & $16-80$ & 43.6 & $2-104$ \\
\hline Salako et al. (Nigeria) (20) & 51 & 33.3 & 66.7 & 41.7 & $21-83$ & & $6-32$ \\
\hline
\end{tabular}


of 482 cases of renal masses were obtained from the 11 studies (Table 1). Based on a pool analysis of the data, there was a predominance of renal masses amongst females $(57.2 \%)$ as opposed to males $(42.8 \%)$ in sub-Saharan Africa. Benin (16) and Nigeria (19) contrarily reported a greater male to female ratio. The mean age of diagnosis was 47.4 years with an age range of 15-83 years. Pooled results from the reviewed data showed a mean duration of symptoms from onset to presentation at 17.6 months with a range of 1-192 months. Most published literature in West Africa reported flank pain, hematuria, and lumbar mass as the commonest clinical presentation with lumbar mass being highlighted in all the studies reviewed (10-17, 19, 20). Smoking $(10,20)$, hypertension $(10,16,20)$, obesity (20), family history (14), and exposure to industrial dyes (14) were the risk factors associated with renal malignancy reported from the sub-Saharan literature (Table 2). The data have shown that most patients in sub-Saharan Africa presented with locally advanced to metastatic disease. Only a few studies from Togo (10) and Nigeria (20) showed a higher percentage of patients presenting with clinically localized disease $(68.8 \%$ and $47.1 \%$, respectively). Anemia, varicocele, hypertension, and pleural effusion were common renal cancer-related complications reported by Tengue et al. (10), Tijani et al. (14), and Salako et al. (20). Histological reports from sub-Saharan nations revealed that RCC was the commonest histological type of cancer with clear cell carcinoma being the most dominant variant at an average of $61.6 \%$ (Table 3 ). The average tumor size from four publications $(10,11,14,17)$ was $15.1 \mathrm{~cm}$ with a range of $2.4-30 \mathrm{~cm}$. An average of $74.4 \%$ of patients presenting with renal masses were managed with radical nephrectomy. However, data from Senegal and Nigeria revealed 1.4\% and $5.3 \%$ of renal masses were managed with partial nephrectomy. Reports from Togo (10) and Nigeria $(14,18,20)$ mentioned the use of immunotherapy in some patients with advanced disease. Sunitinib, bevacizumab, interferon alpha, and sorafenib were the immunotherapeutic options available in these studies (Table 4). A study from Senegal by Gueye et al. (12) reported that $40 \%$ of patients could not receive treatment due to the disease being in the advanced stage while Tijani et al. (14), Mbaeri et al. (15), and Badmus et al. (19), reported patients with unresectable tumor during laparotomy.

Table 2: Clinical manifestation, risk factors, complications, and diagnostics modalities of renal cell carcinoma

\begin{tabular}{|c|c|c|c|c|c|c|c|}
\hline \multirow{2}{*}{ Study } & \multicolumn{3}{|c|}{ Clinical presentation } & \multirow[b]{2}{*}{ Risk factors } & \multirow{2}{*}{$\begin{array}{l}\text { Associated } \\
\text { complications }\end{array}$} & \multirow{2}{*}{$\begin{array}{l}\text { Diagnostic } \\
\text { modalities }\end{array}$} & \multirow{2}{*}{$\begin{array}{l}\text { Imaging } \\
\text { findings of } \\
\text { tumors }\end{array}$} \\
\hline & $\begin{array}{c}\text { Flank pain } \\
(\%)\end{array}$ & $\begin{array}{c}\text { Hematuria } \\
(\%)\end{array}$ & $\begin{array}{c}\text { Lumbar mass } \\
(\%)\end{array}$ & & & & \\
\hline Tengue et al. & 90.6 & 28.1 & 9.3 & $\begin{array}{l}\text { Smoking, } \\
\text { hypertension }\end{array}$ & Severe anemia & $\begin{array}{l}\text { CT-scan, } \\
\text { ultrasound }\end{array}$ & $\begin{array}{l}\text { Solid: } 93.7 \% \text {; } \\
\text { cystic: } 6.3 \%\end{array}$ \\
\hline Fall et al. & 87.8 & & 77 & & & & \\
\hline Gueye et al. & & & 70.8 & & & $\begin{array}{l}\text { Ultrasound, } \\
\text { IVU }\end{array}$ & \\
\hline Ahmed et al. & 74.9 & 57.9 & 86 & & & & \\
\hline Tijani et al. & 86 & 40.6 & 90 & $\begin{array}{l}\text { Family history, } \\
\text { smoking, dyes } \\
\text { exposure }\end{array}$ & $\begin{array}{l}\text { Anemia, } \\
\text { pedal edema, } \\
\text { Varicocele }\end{array}$ & CT-Scan & Solid: $100 \%$ \\
\hline Mbaeri et al. & 78.9 & 522.6 & 78.9 & & & $\begin{array}{l}\text { Ultrasound, } \\
\text { IVU }\end{array}$ & \\
\hline Avakoudjo et al. & 100 & & 48.4 & Hypertension & $\begin{array}{l}\text { Anemia, } \\
\text { Varicocele }\end{array}$ & $\begin{array}{l}\text { CT-scan, } \\
\text { ultrasound, } \\
\text { IVU }\end{array}$ & \\
\hline Coulibaly et al. & & & 66.7 & & & & \\
\hline Badmus et al. & 94.4 & 50.0 & 83.3 & & $\begin{array}{l}\text { Anemia, pleu- } \\
\text { ral effusion }\end{array}$ & $\begin{array}{l}\text { Ultrasound, } \\
\text { IVU }\end{array}$ & \\
\hline Salako et al. & 7.9 & 11.8 & $37.2 \%$ & $\begin{array}{l}\text { Hypertension, } \\
\text { smoking, } \\
\text { obesity }\end{array}$ & & $\begin{array}{l}\text { CT-scan, } \\
\text { ultrasound, } \\
\text { IVU }\end{array}$ & \\
\hline
\end{tabular}

CT-scan: computed tomography scan; IVU: intravenous urography. 
Table 3: Renal tumor size, clinical staging, and commonest histological types in sub-Saharan Africa

\begin{tabular}{|c|c|c|c|c|c|c|c|}
\hline \multirow[t]{2}{*}{ Study } & \multirow{2}{*}{$\begin{array}{l}\text { Incidental } \\
\text { finding } \\
(\%)\end{array}$} & $\begin{array}{c}\text { Tumor } \\
\text { size in } \\
\text { centimeters }\end{array}$ & \multirow[t]{2}{*}{ Range } & $\begin{array}{l}\text { Clinical } \\
\text { staging }\end{array}$ & \multirow[t]{2}{*}{$\begin{array}{c}\text { Locally } \\
\text { advanced }\end{array}$} & \multirow[t]{2}{*}{$\begin{array}{l}\text { Advanced/ } \\
\text { metastatic }\end{array}$} & \multirow[t]{2}{*}{ Commonest histological types } \\
\hline & & Mean & & Localized (\%) & & & \\
\hline Tengue et al. & 3.1 & $12.8 \pm 4.3$ & $5-25$ & 68.8 & 9.4 & 21.8 & $93.1 \%$ (clear cell RCC) \\
\hline Fall et al. & 2.7 & 12 & $2.4-26$ & $\mathrm{~T} 2(39.2)$ & $\mathrm{T} 3(33.7)$ & 31 & $63.5 \%(\mathrm{RCC})$ \\
\hline Gueye et al. & & & & & & 25 & $93 \%(\mathrm{RCC})$ \\
\hline Ahmed et al. & & & & 30.1 & 63.9 & 60.3 & $59 \%$ (clear cell RCC) \\
\hline Tijani et al. & 1.5 & 22 & $12-30$ & 6.3 & 60.9 & 36 & 60\% (clear cell RCC) \\
\hline Mbaeri et al. & & & & 21.1 & 21.1 & 57.8 & $53.8 \%$ (clear cell RCC) \\
\hline $\begin{array}{l}\text { Avakoudjo } \\
\text { et al. }\end{array}$ & & & & $\mathrm{T} 2(43.3)$ & $\mathrm{T} 3(13.3)$ & $\mathrm{T} 4(43.3)$ & $58.8 \%$ (clear cell RCC) \\
\hline $\begin{array}{l}\text { Coulibaly } \\
\text { et al. }\end{array}$ & & $13.6 \pm 5.8$ & $7.8-21.1$ & 40 & & 40 & $95.8 \%(\mathrm{RCC})$ \\
\hline $\begin{array}{l}\text { Muhammed } \\
\text { et al. }\end{array}$ & 11.8 & & & 11.8 & & 90 & $74.5 \%$ (clear cell RCC) \\
\hline Badmus et al. & & & & 11.1 & & 88.9 & $72.2 \%$ (RCC) $33 \%$ (clear cell RCC) \\
\hline Salako et al. & 5.9 & & & 47.1 & 35.3 & 17.6 & $60.8 \%$ (clear cell RCC) \\
\hline
\end{tabular}

RCC: renal cell carcinoma.

\section{Discussion of the Recommended Standard of Care \\ Diagnosis}

History and physical exam are important components of assessing a renal mass. The relevant clinical presentation including hematuria, flank pain, and lumbar mass should be ascertained. All possible risk factors or etiologies should be sought. Physical exam findings of varicocele or pedal edema could depict vascular involvement of the tumor or inferior vena cava (IVC) invasion. Though most authors reported the clinical triad of RCC, the presence of a lumbar mass was reported in all the studies reviewed from the sub-Saharan region (10-20). A complete blood count (CBC), renal function (creatinine, estimated glomerular filtration rate), liver function (alanine transaminase, aspartate aminotransferase), and bony markers (alkaline phosphatase, calcium) should be evaluated $(1,9)$. In the presence of an elevated creatinine, a renal scintigraphy should be performed to assess renal function. Computed tomographic scan (CTscan) is the imaging of choice with about $90 \%$ accuracy for renal masses (Figures 1 and 2). Renal malignancy is most likely when contrast attenuation of 10-20 Hounsfield Unit (HU) is obtained for a renal mass (9). CT scan is essential for staging renal cancer, lymph node assessment, as well as identification of metastasis. A chest CT is ideal for assessing metastasis when findings of chest $\mathrm{x}$-ray are equivocal. Magnetic resonance imaging (MRI) and Doppler ultrasound are useful for determining the IVC involvement. Findings by Tengue et al., Tijani et al., Avokoudjo et al. and Salako et al. highlighted the use of CT-scan and ultrasound to diagnose and stage renal malignancies. The use of intravenous urogram (IVU) though limited was reported by some studies $(12,15,19,20)$ from the sub-Saharan region. It may have been useful for large tumors that may have distorted the renal parenchyma.

CT-scan or MRI findings of cystic renal lesion, Bosniak class I and class II, have minimum risk of malignancy and require no follow-up. However, Bosniak class IIF has a $10 \%$ risk of malignancy and follow-up with ultrasound or CT is recommended. Bosniak class III and IV have 65\% and $92 \%$ risk of malignancy respectively and require treatment (Figure 2) (9).

The use of renal mass biopsy is optional and should be performed if the histological results will change the decision of the management. Renal mass biopsy is essential for patients with metastatic disease or hematological malignancy (lymphoma) (1) who are candidates for systemic therapy. The percutaneous ultrasound or CT-guided core biopsy approach has proven to be safe $(1,9)$. The sensitivity and specificity of renal mass biopsy for the diagnosis of renal malignancy are high, especially for RCC (21). 
Table 4: Treatment modalities for renal tumors and outcome of the disease and treatment in sub-Saharan Africa

\begin{tabular}{|c|c|c|c|c|c|c|}
\hline \multirow[b]{2}{*}{ Study } & \multicolumn{3}{|c|}{ Treatment options } & \multirow[b]{2}{*}{ Others } & \multirow[b]{2}{*}{$\begin{array}{l}\text { Rate of } \\
\text { recurrence }\end{array}$} & \multirow[b]{2}{*}{ Outcome } \\
\hline & $\begin{array}{l}\text { Radical } \\
\text { nephrectomy } \\
(\%)\end{array}$ & $\begin{array}{l}\text { Partial } \\
\text { nephrec- } \\
\text { tomy }(\%)\end{array}$ & Anti-angiogenics & & & \\
\hline Tengue et al. & 90.6 & & $9.4 \%$ (Sunitinib) & $6.9 \%(\mathrm{LND})$ & $9.4 \%$ & $28.1 \%$ (mortality) \\
\hline Fall et al. & 58.1 & 1.4 & & & $12.2 \%$ & $47.3 \%$ mortality \\
\hline Gueye et al. & 60 & & & $\begin{array}{l}40 \% \text { received no } \mathrm{Rx} \text { due } \\
\text { to advanced disease }\end{array}$ & & $\begin{array}{l}38 \% \text { (1-year } \\
\text { mortality) }\end{array}$ \\
\hline Ahmed et al. & & & & & & $\begin{array}{l}20 \text { months (median } \\
\text { survival) }\end{array}$ \\
\hline Tijani et al. & 70.3 & & $\begin{array}{l}29.6 \% \text { (bevaci- } \\
\text { zumab, inter- } \\
\text { feron alpha) }\end{array}$ & 4 unresectable tumors & & $\begin{array}{l}\text { All T4 and M1 were } \\
\text { dead within a year }\end{array}$ \\
\hline Mbaeri et al. & 57.9 & 5.3 & & 1 unresectable tumor & & $\begin{array}{l}\text { Average follow-up } \\
\text { ( } 4 \text { months) }\end{array}$ \\
\hline Avakoudjo et al. & 56.5 & & & & & $\begin{array}{l}8.7 \% \text { perioperative } \\
\text { mortality, most lost } \\
\text { to follow-up }\end{array}$ \\
\hline Coulibaly et al. & 100 & & & & & \\
\hline Muhammed et al. & 100 & & $\begin{array}{l}7.8 \% \text { adjuvant } \\
\text { immunotherapy }\end{array}$ & & & $\begin{array}{l}90 \% \text { died } \\
\text { within 1-year of } \\
\text { nephrectomy }\end{array}$ \\
\hline Badmus et al. & 72.2 & & & $\begin{array}{l}11 \% \text { unresectable } \\
\text { tumor }\end{array}$ & & $7.6 \%$ mortality \\
\hline Salako et al. & 78.4 & & $\begin{array}{l}7.8 \% \text { sunitinib/ } \\
\text { sorafenib }\end{array}$ & & & \\
\hline
\end{tabular}

LND: lymph node dissection.

\section{Management of Localized Renal Cell Carcinoma (cT1-T2, N0 M0) \\ cT1a}

It is recommended that patients with cTla renal tumors should be offered partial nephrectomy as it is associated with good oncological outcomes and minimizes the risk of chronic kidney disease (1). Partial nephrectomy or nephron sparing procedures should be considered for patients with bilateral tumors, tumors of solitary kidney, or patients with familial renal tumor. However, in candidates undergoing partial nephrectomy, a negative surgical margin should remain a priority. More complex tumors not amenable to partial nephrectomy can undergo radical nephrectomy. In elderly patients who are frail and cannot withstand surgery, thermal ablation of the renal tumor is an option but a biopsy is required before the procedure. Active surveillance has been advocated for select patients but regular follow-up with imaging for 3-6 months is warranted. $c T 1 b$

Tumor greater than 4 centimeters $(\mathrm{cm})$ but $<7 \mathrm{~cm}$ is amenable to partial nephrectomy either open, laparoscopic, or robotic as evidenced by the acceptable oncological results (9). When partial nephrectomy is not technically feasible, a laparoscopic radical nephrectomy should be considered over open radical nephrectomy as it is associated with less postoperative pain and better recovery $(22,23)$. Active surveillance has shown some benefits in selected patients with RCC following renal mass biopsy. Ablative therapy should not be considered an option in this subset as complete thermal ablation is challenging in tumors $>4 \mathrm{~cm}(9)$.

cT2

Patients with renal tumor $>7 \mathrm{~cm}$ limited to the kidney can undergo open or laparoscopic radical nephrectomy 


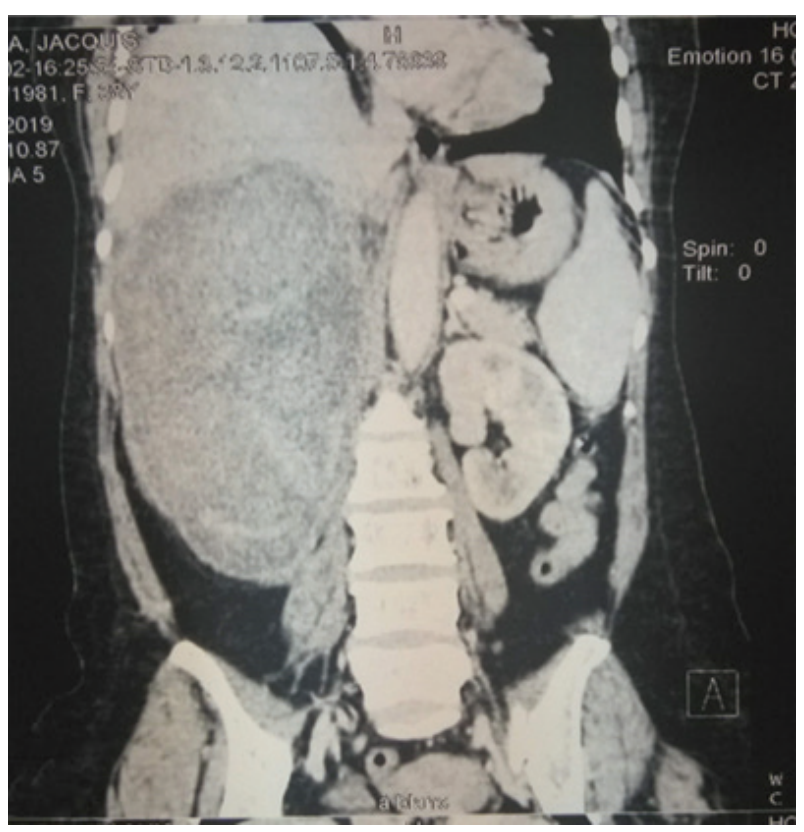

Figure 1: A contrast coronal CT-scan showing a hyper vascularized right $\mathrm{T} 4$ renal tumor found to have affected the renal vein, IVC, and inferior margin of the liver.

$(24,25)$. Extended partial nephrectomy is discouraged in this population (9).

It may be debatable that patients from the sub-Saharan settings are offered partial nephrectomy for localized disease as the technique itself has not been widely applied amongst urologists in the region. The lack of resources, cost of active surveillance, and the loss to follow-up of most patients in these settings render the nephron-sparing procedure less desirable. Radical nephrectomy may provide a better oncological result though the risk of chronic kidney disease is not eliminated.

\section{Management of Locally Advanced Renal Cell Carcinoma (T1-T2, N1, M0 or T3, N0/N1, M0)}

\section{T3}

Approximately $4-10 \%$ of RCCs will involve the IVC (9, 26). Tumors $>7 \mathrm{~cm}$ that have not invaded the Gerota fascia but involve the IVC are managed with radical nephrectomy and thrombectomy as this approach has provided acceptable morbidity in the absence of metastasis $(9,26)$. When there is an upper pole tumor, ipsilateral involvement of the adrenal gland intraoperatively or following imaging, an ipsilateral adrenalectomy is ideal as $1.9-7.5 \%$ of renal malignancy will involve the ipsilateral adrenal gland (27). Routine regional lymphadenectomy is not recommended in localized disease but patients with clinical (N1, M0) disease are candidates for regional lymph node dissection. The



Figure 2: A contrast CT-scan showing a cystic right renal tumor in the upper pole with associated hydronephrosis. Courtesy: Grand Yoff Hospital.

role of neoadjuvant and adjuvant therapy for RCC remains unclear.

The evidence has shown that most patients in sub-Saharan Africa present with locally advanced to metastatic disease (11-19). Open radical nephrectomy has been well adopted for locally advanced disease in Africa. Evidence from published literature in the region has shown that an average of $74.4 \%$ of patients presenting with renal masses were managed with radical nephrectomy. A 16-year retrospective study by Tengue et al. (10) in Togo involving 32 patients with RCC who underwent surgery showed that $6.9 \%$ of patients required lymph node dissection.

\section{Treatment of Advanced Disease (T4 N0/N1 M0)} T4

Surgical resection is the only available treatment option for T4 tumors. These tumors are best managed in high-volume centers with resection of the ipsilateral adrenal gland and part of the liver, pancreas, or diaphragm if required (9). Most of these patients already have occult lymph node involvement 
which demands regional lymph node dissection. Despite these gestures, the 5-year overall survival is poor, and the surgical morbidity of extensive resection should be weighed against the oncological benefits $(28,29)$.

Studies by Tijani et al. (14) and Muhammed et al. (18) from Nigeria showed a poor prognosis of T4 disease despite intervention with an overall 1-year disease survival of less than $10 \%$.

\section{Treatment of Metastatic Disease}

(Any T, Any N + M1)

Cytoreductive nephrectomy is recommended in patients with metastatic disease. Studies have provided better results when nephrectomy is combined with systemic therapy as compared to systemic therapy alone (30). Cytoreductive nephrectomy and interferon alpha help to improve survival rates in patients with RCC (8). In well-selected patients, metastasectomy following nephrectomy has given good results. Metastasis to the pancreas, lungs, bone, and adrenal gland has a more favorable prognosis (9). Radiotherapy to a local or distant site of metastasis (brain, bone) in patients with RCC can relieve pain. Chemotherapy plays a limited role as a systemic therapy in RCC, especially clear cell metastatic RCC. However, Gemcitabine, 5- Fluorouracil, and Doxorubicin have some documented effect (8).

\section{Immunotherapy}

Data have shown that interferon alpha and Bevacizumab increase the response rate and progression free survival in metastatic RCC compared to interferon alpha alone (8). Ipilimumab plus nivolumab in treatment-naïve patients with clear cell RCC provide a better survival rate compared to sunitinib (8). These drugs are associated with significant side effects and should be administered by a multidisciplinary team.

The use of systemic therapy following cytoreductive nephrectomy in patients with advanced or metastatic RCC is not well-documented in West Africa. However, a few studies from Togo (10) and Nigeria $(14,18,20)$ documented the use of immunotherapy in some patients with advanced disease. Sunitinib, bevacizumab, interferon alpha, and sorafenib were the available immunotherapeutic options for these studies. A study by Muhammed et al. documented that 4 (7.8\%) patients who had adjuvant treatment (immunotherapy or vascular endothelial growth factor (VEGF)-tyrosine kinase inhibitors) had a better prognosis (18). The management of advanced and metastatic disease was not well-documented in the review from sub-Saharan nations. Moreover, most of the institutions lack the recommended immunotherapeutic agents or rather referred the patients to medical oncology for further management. It is important that urologists and oncologists from sub-Saharan Africa coordinate with relevant pharmaceutical companies for provision or supply of these agents at an affordable cost.

\section{Follow-up}

Post-surgical follow-up should be based on individual risk assessment. Low-risk patients should have imaging (CT, MRI, or ultrasound) performed within a year following surgery. Chest X-ray should be performed yearly for the first 3-6 years to check for metastasis. Moderate- to high-risk patients will require an MRI or CT-scan 6 months after surgery. A yearly chest X-ray or chest CT-scan is advisable for up to 5 years.

\section{Outcome}

Data from the review showed heterogenous results on the perioperative mortality following radical nephrectomy in the sub-Saharan region. However, analysis of reports from Nigeria $(14,19)$, Togo (16), and Mali (17) showed a perioperative mortality of $5.1 \%$ following radical nephrectomy. Most of these deaths were due to perioperative hemorrhage or pulmonary complications. These data are comparable to the results of a systemic review of RCC in Nigeria which showed a perioperative mortality of radical nephrectomy ranging from $6.3 \%$ to $7.8 \%$ (5). These figures are much higher than the perioperative mortality of radical nephrectomies in Europe and North America which is about 2.8\% (5). The late patient presentation, the lack of expertise for nephron sparing procedures, and the underequipped intensive care unit have contributed to this dismal result. However, more funding, quality imaging, and diagnostics as well as human expertise are required for uro-oncological care in the region with promotion of a multidisciplinary approach. Urologists, medical oncologists, radio-oncologists, and radiologists should communicate to provide the best standard of care and adopt a guideline that is practical, feasible but evidence based. This is only achievable through proper documentation and coordinated research in the African context.

Extrapolation of the 5-year overall survival of RCC following treatment is challenging as the reportings are heterogenous. Nevertheless, a retrospective review of 61 patients with RCC in Nigeria had a 5-year survival of $46 \%$ for young adults and $26 \%$ for older adults using the KaplanMeier analysis (13). Another contemporary series in Nigeria showed a lower 5-year survival of RCC of less than $10 \%$ following radical nephrectomy (18). Better cancer-awareness programs, maintaining an effective cancer-treatment guideline, and establishing a cancer registry in the sub-region are required to achieve 5-year overall survival rates of $55 \%$ and $73 \%$ as obtained from Europe and the United States, respectively (5).

\section{Conclusion}

The management of renal cell cancer is challenging. A multidisciplinary approach is effective for diagnosis, staging, and treatment. Active surveillance, thermal ablation, 
partial nephrectomy, radical nephrectomy, cytoreductive nephrectomy, and immunotherapy are being recommended as various modalities by guidelines for various stages of RCC. However, open radical nephrectomy is most widely adopted as a treatment option at various stages of the disease in sub-Saharan Africa due to its cost-effectiveness, applicability at various stages, and the reduced cost of follow-up. Nevertheless, most patients present with advanced disease in the region and despite surgery the prognosis is poor.

\section{Conflict of Interest}

The authors declare no conflict of interest regarding this article.

\section{Funding}

No external funding was available which needs to be disclosed.

\section{Authors' contribution}

A.C., M.J., and B.Y. were responsible for the conceptual design. Analysis, drafting, and critical revision of the article were performed by A.C., M.J., B.Y., S.C.K., A.D., M.M., and M.N. L.N., I.L., and S.G. were responsible for the final approval of the article.

\section{References}

1. Campbell S, Uzzo RG, Allaf ME, Bass EB, Cadeddu JA, Chang A, et al. Renal mass and localized renal cancer: AUA guideline. J Urol. 2017 Sep;198(3):520-9. https://doi.org/10.1016/j. juro.2017.04.100

2. Ferlay J, Soerjomataram I, Dikshit R, Eser S, Mathers C, Rebelo $\mathrm{M}$, et al. Cancer incidence and mortality worldwide: Sources, methods and major patterns in GLOBOCAN 2012. Int J Cancer. 2015;136:E359. https://doi.org/10.1002/ijc.29210

3. Bray F, Ferlay J, Soerjomataram I, Siegel RL, Torre LA, Jemal A. Global cancer statistics 2018: GLOBOCAN estimates of incidence and mortality worldwide for 36 cancers in 185 countries. CA: Cancer J Clin. 2018 Nov;68(6):394 424. https://doi. org/10.3322/caac. 21492

4. Zekri J, Dreosti LM, Ghosn M, Hamada E, Jaloudi M, Khorshid $\mathrm{O}$, et al. Multidisciplinary management of clear-cell renal cell carcinoma in Africa and the Middle East: Current practice and recommendations for improvement. J Multidiscip Healthcare. 2015;8:335. https://doi.org/10.2147/JMDH.S85538

5. Atanda AT, Haruna MS. Renal cell carcinoma in Nigeria: A systematic review. Sahel Med J. 2017 Oct 1;20(4):137. https:// doi.org/10.4103/smj.smj_67_16

6. Rashidkhani B, Akesson A, Lindblad P. Alcohol consumption and risk of renal cell carcinoma: A prospective study of Swedish women. Int J Cancer. 2005;117:848. https://doi.org/10.1002/ ijc. 21231

7. Lee JE, Mannisto S, Spiegelman D, Hunter DJ, Bernstein L, Van Den Brandt PA, et al. Intakes of fruit, vegetables, and carotenoids and renal cell cancer risk: A pooled analysis of 13 prospective studies. Cancer Epidemiol Biomarkers Prev. 2009;18(6):1730-9. https://doi.org/10.1158/1055-9965.EPI-09-0045

8. Ljungberg B, Bensalah K, Canfield S, Dabestani S, Hofmann F, Hora M, et al. EAU guidelines on renal cell carcinoma: 2014 update. Eur Urol. 2015;67(5), 913-24. https://doi.org/10.1016/j. eururo.2015.01.005

9. Rendon RA, Kapoor A, Breau R, Leveridge M, Feifer A, Black PC, et al. Surgical management of renal cell carcinoma: Canadian kidney cancer forum consensus. Can Urol Assoc J. 2014 May;8(5-6):E398. https://doi.org/10.5489/cuaj.1894

10. Tengue K, Kpatcha TM, Sonhaye L. Cancer du rein de l'Adulte au Togo: Fréquence, diagnostic, traitement et évolution. Revue Africaine d'Urologie et d'Andrologie. 2015 Jul 2;1(4):177-82.

11. Fall B, Diao B, Sow Y, Sarr A, Thiam A, Fall PA, et al. Le cancer du rein de l'adulte au Sénégal: Aspects épidémiologiques et cliniques actuels et évolution du profil sur les deux dernières décennies. Progrès en Urologie. 2011 Sep 1;21(8):521-6. https:// doi.org/10.1016/j.purol.2011.02.013

12. Gueye SM, Diallo B, Fall PA, Ndoye AK, Konan PG, Abdallahi MO, et al. Malignant kidney tumors in adults in Senegal: Diagnostic and therapeutic problems. Dakar Med. 1998;43(2):213-15.

13. Ahmed M, Oyelowo N, Bello A, Lawal AT, Maitama HY, Abdulsalam K, et al. Peculiarities of renal cell carcinoma in young adults. Arch Int Surg. 2018;8:59-62. https://doi.org/10.4103/ais.ais_33_18

14. Tijani KH, Anunobi CC, Ezenwa EV, Lawal A, Habeebu MY, Jeje EA, et al. Adult renal cell carcinoma in Lagos: Experience and challenges at the Lagos University Teaching Hospital. African J Urol. 2012;18(1):20-3. https://doi.org/10.1016/j.afju.2012.04.005

15. Mbaeri TU, Orakwe JC, Nwafor AM, Oranusi CK, Ulebe AO. Malignant renal tumours in adults in Nnamdi Azikiwe University Teaching Hospital, Nnewi, Nigeria. Nigerian J Med. 2012;21(4):377-80.

16. Avakoudjo DG, Hounnasso PP, Traore MT, Natchagandé G, Pare AK, Tore-Sanni R, et al. Experience with managing solid kidney tumours in Cotonou, Benin Republic. J West Afr Coll Surg. 2014 Oct;4(4):100.

17. Coulibaly MT, Sissoko I, Berthé A, Amadou I, Traore B, Ly M, et al. Management of kidney cancers in Urology Department of the Gabriel Toure University Hospital/Bamako. Surg Sci. 2018 Jun 15;9(06):183. https://doi.org/10.4236/ss.2018.96021

18. Muhammed A, Ahmad B, Yusuf MH, Almustapha LA, Abdullahi S, Tijjani LA. Pathologic characteristics and management of renal cell carcinoma in Zaria, Nigeria. SubSaharan Afr J Med. 2015 Jan 1;2(1):1. https://doi.org/10.4103/ 2384-5147.151559

19. Badmus TA, Salako AB, Arogundade FA, Sanusi AA, Adesunkanmi AR, Oyebamiji EO, et al. Malignant renal tumors in adults: A ten-year review in a Nigerian hospital. Saudi J Kidney Dis Transpl. 2008 Jan 1;19(1):120.

20. Salako AA, Badmus TA, Badmos KB, David RA, Laoye A, Akinbola IA, et al. Renal cell carcinoma in a semi-urban population of south-western Nigeria. East Afr Med J. 2017 Jan;94(1):37-43.

21. Patel HD, Johnson MH, Pierorazio PM, Sozio SM, Sharma R, Iyoha E, et al. Diagnostic accuracy and risks of biopsy in the diagnosis of a renal mass suspicious for localized renal cell carcinoma: Systematic review of the literature. J Urol. 2016;195(5):1340-7. https://doi.org/10.1016/j.juro.2015.11.029

22. Lane BR, Campbell SC, Gill IS. 10-year oncological outcomes after laparoscopic and open partial nephrectomy. J Urol. 2013;190:44-9. https://doi.org/10.1016/j.juro.2012.12.102 
23. Fenn NJ, Gill IS. The expanding indications for laparoscopic radical nephrectomy. BJU Int. 2004;94:761-5. https://doi. org/10.1111/j.1464-410X.2004.05028.X

24. Woldrich JM, Palazzi K, Stroup SP, Sur RL, Parsons JK, Chang D, et al. Trends in the surgical management of localized renal masses: Thermal ablation, partial and radical nephrectomy in the USA, 1998-2008. BJU Int. 2013;111(8):1261-8. https://doi.org/10.1111/j.1464-410X.2012.11497.x

25. Steinberg AP, Finelli A, Desai MM, Abreu SC, Ramani AP, Spaliviero M, et al. Laparoscopic radical nephrectomy for large (greater than $7 \mathrm{~cm}, \mathrm{~T} 2$ ) renal tumours. J Urol. 2004;172(6 Part 1): 2172-6. https://doi.org/10.1097/01.ju.0000140961.53335.04

26. Feifer A, Savage C, Rayala H, Lowrance W, Gotto G, Sprenkle P, et al. Prognostic impact of muscular venous branch invasion in localized renal cell carcinoma cases. J Urol. 2011;185(1):37-42. https://doi.org/10.1016/j.juro.2010.08.084

27. Kletscher BA, Qian J, Bostwick DG, Blute ML, Zincke H. Prospective analysis of the incidence of ipsilateral adrenal metastasis in localized renal cell carcinoma. J Urol. 1996;155(6):1844-6. https://doi.org/10.1016/S0022-5347(01)66026-9

28. Margulis V, Sanchez-Ortiz RF, Tamboli P, Cohen DD, Swanson DA, Wood CG. Renal cell carcinoma clinically involving adjacent organs: Experience with aggressive surgical management. Cancer. 2007;109(10):2025-30. https://doi.org/10.1002/ cncr.22629

29. Frank I, Blute ML, Cheville JC, Lohse CM, Weaver AL, Zincke H. An outcome prediction model for patients with clear cell renal cell carcinoma treated with radical nephrectomy based on tumour stage, size, grade and necrosis: The SSIGN score. J Urol. 2002;168(6):2395-400. https://doi.org/10.1016/ S0022-5347(05)64153-5

30. Flanigan RC, Mickisch G, Sylvester R, Tangen C, Van Poppel $\mathrm{H}$, Crawford ED. Cytoreductive nephrectomy in patients with metastatic renal cancer: A combined analysis. J Urol. 2004;171(3):1071-6. https://doi.org/10.1097/01.ju.0000110610. 61545.ae 